\title{
Study about the depletion of nutrients (NPK) by weeds in mustard
}

\author{
Jaibir Tomar ${ }^{1}$ and Rashmi Nigam ${ }^{2} *$ \\ ${ }^{1}$ Department of Agronomy, ${ }^{2}$ Department of Plant Pathology, J.V. College, Baraut, CCSU, Meerut \\ *Email: neelu.nigam @gmail.com
}

\begin{abstract}
Oilseed crops occupy second major group among agricultural crops. Oilseed crop having limited area of cultivation confined to North India. Seed yield of mustard with increase in fertilizer and irrigation rates. Weeds, a major constraint and their control are essential for successful crop production. Weeds are regarded as one of the major negative factors of crop produce loss due to competition for nutrients, moisture, light and space, which costly and difficult affair as the operation coincides with sowing of other rabi crops). The treatments included fifteen combinations of management systems and weed control measures were included in this study and replicated three times, viz. $\mathrm{M}_{1}$ no fertilizer no irrigation, $\mathrm{M}_{2} 50 \%$ of the recommended fertilizer doses $\left(\mathrm{N}_{40}\right.$ $\left.\mathrm{P}_{20} \mathrm{~K}_{20}\right)+1$ irrigation at flowering stage, $\mathrm{M}_{3} 50 \%$ of the recommended fertilizer doses $\left(\mathrm{N}_{40} \mathrm{P}_{20} \mathrm{~K}_{20}\right)+2$ irrigation at 30 DAS \& flowering stage, $\mathrm{M}_{4} 100 \%$ of the recommended fertilizer doses $\left(\mathrm{N}_{80} \mathrm{P}_{40} \mathrm{~K}_{40}\right)+1$ irrigation at flowering stage, $\mathrm{M}_{5} 100 \%$ of the recommended fertilizer doses $\left(\mathrm{N}_{80} \mathrm{P}_{40} \mathrm{~K}_{20}\right)+2$ irrigation at DAS \& flowering stage and three weed management options $\mathrm{W}_{1}$ weedy check, $\mathrm{W}_{2}$ hand weeding at $30 \mathrm{DAS}, \mathrm{W}_{3}$ Pendimethalin $1 \mathrm{~kg}$ a.i./ha. The experiment conducted in split- plot design and management option in main plot and weed management option in sub plots. In these treatments, hand weeding and pendimethalin application drastically reduced the drain of nutrients by weeds under all the management systems.
\end{abstract}

Key words: Depletion, nutrients, NPK, Weeds, Mustard.

Paper cited: Tomar, J. and Nigam, R. (2018). Study about the depletion of nutrients (NPK) by weeds in mustard. South Asian Journal of Food Technology and Environment, 4(2): 734-737.

\section{Introduction}

Oilseed crops have an important role in agriculture and industrial economy of India. These crops occupy second major group among agricultural crops. Oilseed crop having limited area of cultivation confined to North India and brought about perceptible change in the economy of the farmers of Rajasthan, Uttar Pradesh, Assam, Haryana, Gujarat, Madhya Pradesh and Punjab. Recent research findings have clearly established the mustard crop responds very well to fertilizer and irrigations (Singh et al., 2011) reported that significant enhancement in seed yield of mustard with increase in fertilizer and irrigation rates. It is a long duration and widely spaced row crop. Because of photosensitivity and thermo-sensitivity, this crop is slow growing at the initial stage. Therefore, weed problem is serious issue at this stage. The crop has contended against serious competition from weeds. Weeds are a major constraint and their control is essential for successful crop production. Weeds are regarded as one of the major negative factors of crop produce loss due to competition for nutrients, moisture, light and space .which costly and difficult affair as the operation coincides with sowing of other rabi crops. Moreover, wages are shooting high these days Hand weeding is a very old and effective practice of weed control. However, this practice is so limitation like that untimely rainfall and unavailability of labor at peak time. The only alternative that needs to explore is the use of herbicides. Pendimethalin is the pre-emergence herbicide. The basic concept of use this herbicide is mainly weed free environment at time of germination and growth stages and secondly, fertilizers and irrigation applied to soil has utilized by the crop plants only due to restricted weed growth from herbicide treatment of mustard crop.

\section{Material and Methods}

The present study was carried out Department of Agronomy, during rabi season 2012 at research farm of Janta Vedic College, Baraut 
(Baghpat) U.P. on loam soil in texture having moderate fertility and $\mathrm{pH}$ of 7.5 , low in organic carbon $(0.38 \%)$ and available $\mathrm{N}(155 \mathrm{~kg} / \mathrm{ha})$, available $\mathrm{P} \quad(15.62 \mathrm{~kg} / \mathrm{ha})$ and available $\mathrm{K}$ $(149.62 \mathrm{~kg} / \mathrm{ha})$. The treatments included fifteen combinations of management systems and weed control measures were included in this study and replicated three times, viz. $M_{1}$ no fertilizer no irrigation, $\mathrm{M}_{2} 50 \%$ of the recommended fertilizer doses $\left(\mathrm{N}_{40} \mathrm{P}_{20} \mathrm{~K}_{20}\right)+1$ irrigation at flowering stage, $\mathrm{M}_{3} 50 \%$ of the recommended fertilizer doses $\left(\mathrm{N}_{40} \mathrm{P}_{20} \mathrm{~K}_{20}\right)+2$ irrigation at 30 DAS \& flowering stage, $\mathrm{M}_{4} 100 \%$ of the recommended fertilizer doses $\left(\mathrm{N}_{80} \mathrm{P}_{40} \mathrm{~K}_{40}\right)+1$ irrigation at flowering stage, $\mathrm{M}_{5} 100 \%$ of the recommended fertilizer doses $\left(\begin{array}{lll}\mathrm{N}_{80} & \mathrm{P}_{40} & \mathrm{~K}_{20}\end{array}\right)+2$ irrigation at DAS \& flowering stage and three weed management options $\mathrm{W}_{1}$ weedy check, $\mathrm{W}_{2}$ hand weeding at 30 DAS, $\quad \mathrm{W}_{3}$ Pendimethalin $1 \mathrm{~kg}$ a.i./ha. The experiment conducted in split- plot design and management option in main plot and weed management option in sub plots. The gross plot size was $17.5 \mathrm{~m}^{2}$ and net plot size was $12 \mathrm{~m}^{2}$. After the harvest of Kharif crops paddy in October, land preparation was done as per treatment and sowing was done on 29 October 2011 using Pussa mustard -25 , variety with a seed rate of $5 \mathrm{~kg} / \mathrm{ha}$. The fertilizers applied in furrows as per treatments. The sowing was done at a row-to-row spacing of $45 \mathrm{~cm}$ and plant to plant, spacing $15 \mathrm{~cm}$. thus the required plant population was ensured. The crop was harvest on 15 March 2012.The herbicide was spray as preemergence a day after sowing using spray volume of $500 \mathrm{~L} /$ ha with a knapsack sprayed fitted with flat fan nozzle. The hand weeding was done with the help of kurpi after 30 DAS. The data on weed count and weed biomass was record at 45 DAS with the quadrate of $0.25 / \mathrm{m}^{2}$ at two places under each plot. The percentage nitrogen phosphorus and potassium content of weeds samples collected at different stages of crops growth estimated and the amount of NPK removed was calculated on dry matter basis.

\section{Results and Discussion}

\section{Nitrogen depletion by weeds $(\mathrm{kg} / \mathrm{ha})$}

The removal of nitrogen by weds under $\mathrm{M}_{4}$ management system was significant higher over rest of the management systems (Table 1). All the five management systems differed significantly among themselves management system $\mathrm{M}_{1}$ arrested considerably the depletion of nitrogen by weeds and this system appeared to be significantly superior over other management systems followed by $\mathrm{M}_{2}$ system in cutting drastically the removal of nitrogen by weeds. As regards the weed, control measures both hand weeding and pendimethalin application were effective in checking nitrogen depletion by weeds. Although no significant variation existed between these two treatments as far as nitrogen removal by weeds was concerned but hand weeding had a slight edge over pendimethalin application curtailing the removal of nitrogen by weeds. The reduction in depletion of nitrogen in hand weeding $\left(\mathrm{W}_{2}\right)$ and pendimethalin $\left(\mathrm{W}_{3}\right)$ was about 80 percent as compared to that in weedy check $\left(\mathrm{W}_{1}\right)$.

The interaction effect of management system and weed control measures found significant. Both hand weeding and pendimethalin application reduced markedly the nitrogen depletion by weeds under all the management system when compared with weedy check. Moreover, hand weeding and pendimethalin were equally effective under all the management systems in checking the drain of nitrogen by weeds. The magnitude of loss of nitrogen was significantly higher under management system. $\mathrm{M}_{4}$ as compare to other management system $M_{1}$, pendimethalin had better influence compared to hand weeding where as under rest of the management systems viz. $\mathrm{M}_{2}, \mathrm{M}_{3}$, $\mathrm{M}_{4}$ and $\mathrm{M}_{5}$ hand weeding scored over pendimethalin application in reducing the nitrogen removal by weeds. This results due to better efficiency of both these treatments that caused significant reduction in dry matter production.

\section{Phosphorus depletion by weeds (kg/ha)}

The depletion of phosphorus by weeds under $\mathrm{M}_{5}$ management system enhanced significantly over rest of the management systems enhanced significantly over rest of the management system treatment. All the five management systems varied statistically to each other in affecting the removal of phosphorus by weeds. $M_{1}$ management system was the most effective in curtailing the phosphorus by weeds followed by $\mathrm{M}_{2}$ system. As in the case of nitrogen, the phosphorus removal drastically reduced by hand weeding and pendimethalin application to that of weedy check. Hand weeding and pendimethalin application appeared to be equally effective as no difference of a significant order was found between these two treatments. From the interaction effect (Table 2) it is the evident that both hand weeding and 
pendimethalin application under all the management system down the phosphorus depletion by weeds. The effect of weed control measures in reducing the phosphorus removal by weeds was more pronounce under $\mathrm{M}_{2}$ management system where the loss of phosphorus due to these treatments was minimum as compared to under $\mathrm{M}_{4}$ management system. Under $\mathrm{M}_{1}$ management system pendimethalin application proved superior to hand weeding while under all other management system hand weeding was found either at par with or superior to pendimethalin in arresting the phosphorus loss by weeds.

Table 1: Depletion of $\mathrm{N}, \mathrm{P}$ and $\mathrm{K}$ by weeds (kg/ha) at harvest as influenced by management systems and weed control treatments.

\begin{tabular}{|c|c|c|c|}
\hline Treatment & $\mathbf{N}$ & $\mathbf{P}$ & $\mathbf{K}$ \\
\hline \multicolumn{4}{|l|}{ Management } \\
\hline $\mathrm{M}_{1}$ & 2.95 & 0.35 & 2.51 \\
\hline $\mathrm{M}_{2}$ & 3.43 & 0.39 & 3.06 \\
\hline $\mathrm{M}_{3}$ & 4.22 & 0.44 & 3.44 \\
\hline $\mathrm{M}_{4}$ & 5.26 & 0.52 & 4.14 \\
\hline $\mathrm{M}_{5}$ & 4.77 & 0.57 & 4.68 \\
\hline S.Em. + & 0.15 & 0.01 & 0.16 \\
\hline $\mathrm{CD}(\mathrm{P}=\overline{0.05)}$ & 0.34 & 0.02 & 0.38 \\
\hline \multicolumn{4}{|l|}{ Weed Control } \\
\hline $\mathrm{W}_{1}$ & 8.75 & 0.97 & 7.50 \\
\hline $\mathrm{W}_{2}$ & 1.77 & 0.19 & 1.60 \\
\hline $\mathrm{W}_{3}$ & 1.86 & 0.20 & 1.60 \\
\hline S.Em. + & 0.07 & 0.01 & 0.11 \\
\hline $\mathrm{CD}(\mathrm{P}=\overline{0.05)}$ & & 0.13 & 0.24 \\
\hline
\end{tabular}

Table 2: Depletion of $\mathrm{N}, \mathrm{P}$ and $\mathrm{K}$ by weeds $(\mathrm{kg} / \mathrm{ha})$ at harvest as affected by interaction between management systems and weed control treatments.

\begin{tabular}{|c|c|c|c|c|c|c|c|c|c|}
\hline \multicolumn{9}{|c|}{ Nutrients depletion } & \multirow{3}{*}{$\begin{array}{c}\text { Management } \\
\text { systems }\end{array}$} \\
\hline \multicolumn{3}{|c|}{ Nitrogen } & \multicolumn{3}{|c|}{ Phosphorus } & \multicolumn{3}{|c|}{ Potassium } & \\
\hline $\mathbf{W}_{3}$ & $\mathbf{W}_{2}$ & $\mathbf{W}_{1}$ & $\mathbf{W}_{3}$ & $\mathbf{W}_{2}$ & $\mathbf{W}_{1}$ & $\mathbf{W}_{3}$ & $\mathbf{W}_{2}$ & $\mathbf{W}_{1}$ & \\
\hline 1.14 & 1.30 & 5.10 & 0.16 & 0.18 & 0.71 & 1.36 & 1.40 & 6.08 & $\mathrm{M}_{1}$ \\
\hline 1.64 & 1.46 & 6.07 & 0.18 & 0.17 & 0.82 & 1.65 & 1.44 & 7.20 & $\mathrm{M}_{2}$ \\
\hline 1.65 & 1.53 & 7.13 & 0.21 & 0.20 & 0.92 & 1.92 & 1.87 & 8.87 & $\mathrm{M}_{3}$ \\
\hline 1.75 & 1.80 & 8.87 & 0.24 & 0.23 & 1.10 & 2.37 & 2.35 & 11.05 & $\mathrm{M}_{4}$ \\
\hline 1.82 & 1.88 & 10.33 & 0.19 & 0.19 & 1.33 & 1.99 & 1.77 & 10.54 & $\mathrm{M}_{5}$ \\
\hline- & - & 0.26 & - & - & 0.03 & - & - & 0.16 & S.Em. \pm \\
\hline- & - & 0.77 & - & - & 0.09 & - & - & 0.47 & $\mathrm{CD}(\mathrm{P}=0.05)$ \\
\hline
\end{tabular}

\section{Potassium depletion by weeds (kg/ha)}

The observation on potassium depletion summarized in Table1 show almost similar trend as observed in case of nitrogen and phosphorus depletion by weeds described as above. The depletion of potassium by weeds suffered drastically under $\mathrm{M}_{1}$ management system as $\mathrm{M}_{2}$ in reducing the substantial loss of potassium by weeds management system differed statistically among them and the maximum drain of potassium by weeds occurred under $\mathrm{M}_{5}$ system. Weed control measures had a significant effect in checking the potassium removal by weeds. Both hand weed weeding and pendimethalin application prevented substantially the depletion of potassium by weeds as compared to weedy check. These two treatments reduced the potassium removal by weeds to the extent of 79 percent over weedy check. The interaction between management systems and weed control measures was found significant (Table 2) in respect of potassium depletion by weeds. The removal of potassium was significantly reduced by hand weeding and pendimethalin application in 
comparison to weedy check under all the management system. Pendimethalin application under $\mathrm{M}_{1}, \mathrm{M}_{4}$ and $\mathrm{M}_{5}$ appeared to be slightly better hand weeding while hand weeding had an edge over pendimethalin under $\mathrm{M}_{2}$ and $\mathrm{M}_{3}$ management system in decreasing the phosphorus depletion by weeds. The results showed a positive relationship between fertilizer and irrigation and removal of $\mathrm{N}, \mathrm{P}$ and $\mathrm{K}$ by weeds. Similar confirmed with the Jain et al., (2008); Meena and Sah (2011). They reported that the weeds accumulates considerable amount of nutrients at the cost of the crop. Even at higher dose of nutrients, weeds compete strongly for nutrients than the crop.

\section{Conclusion}

From this experiment, it could be concluded that hand weeding and pendimethalin application drastically reduced the drain of nutrients by weeds under all the management systems.

\section{References}

1. Jain, A.K., Jaitendra M., Kumar, S. and Panwar, J.D.S (2008). Comparative study on effect different levels of nitrogen and weed control methods on mustard. Advances in Plant Sciences, 21(1): 371-372

2. Meena, M.L. and Sah, D. (2011). Effect of weed control and fertilization on yield attributes and seed yield of mustard (Brassica juncea L.) under western plains of U.P. Environment and Ecology, 29(2A): 929-931.

3. Singh, F., Kumar, M., Kumar, P. and Pal, S. (2011). Effect of irrigation, fertility and topping on Indian mustard (Brassica juncea L.) Progressive Agriculture, 11(2): 477-478. 